\title{
Treaty-Related Research and Versions of New Zealand History
}

\author{
Alan Ward
}

Prodigious research efforts and outpourings of new writing on Maorisettler history have been associated largely with the enactment into New Zealand's statute law in 1975 of the Treaty of Waitangi. The treaty, signed between the British Crown and some five hundred Maori chiefs in 1840, had been drawn up by British officials and their missionary advisers for the purposes of securing Maori consent, under Article I of the treaty, to the transfer of sovereignty of the New Zealand islands to the British Crown. It was the act of two "executives" and, of itself, it had no force in domestic law, although it did influence British governments subsequently to uphold Maori rights to land, recognized in Article II. However, the treaty guarantee was not considered by New Zealand officials or courts to prevail against the Crown's prerogative rights, under British common law, to foreshores, harbors, and navigable waters (McHugh 1991:112-116).

The Crown's own dubious land purchases-from some but not all of the rightholders-caused Maori to begin to form supratribal combinations such as the kingitanga (the 'King movement') to control landselling factions. The anxiety of the settlers and British officials that colonization of the North Island would be effectively blocked caused the British army to be used by Governor Gore Browne over the Waitara purchase in Taranaki in 1860 and by Governor George Grey to attack the Waikato district, the heart of the kingitanga, in 1863 (Sinclair 1957). Thereafter New Zealand governments passed legislation through the settler-dominated parliament giving authority to confiscate Maori land and to take roads and surveys through it. Treaty guarantees could not prevail against these statutory powers. Even the Native Rights Act of 1865, which gave statutory authority to the third article of the treaty-according Maori the rights and privileges of British subjects-proved a double-edged weapon. It enabled Maori to 
bring actions in the Supreme Court in defense of their legal rights and led, in 1867, to their representation in parliament; it also enabled the government to treat those who took up arms against them as rebels rather than foreign belligerents-and to hang them (Ward 1974: 167-193).

Meanwhile, sections of Maoridom had nurtured a different view of the treaty, the Maori-language version which was the one most had signed. In that version they had ceded to the British, under Article I, kawanatanga or "governorship"; under Article II they were confirmed in their tino rangatiratanga or "full chieftainship" of their lands, and other taonga (valued things). The British did indeed intend to support the local authority of chiefs, then becoming Christian, but their efforts to define chiefly authority in the emergent state were miserable; indeed, beneath a patina of bribes and blandishments they set out to undermine chiefly authority in order to secure the land. Many chiefs who sought cooperation with the government were driven in the end to join the military resistance of the kingitanga, or of the politico-religious "prophets" whose guerrilla tactics carried the wars into the early 1870s (Ward 1974:194-223).

After the wars, Maori leaders attempted a whole variety of strategies to secure recognition of their rangatiratanga, and of mana Maori motuhake, "Maori self-determination." The kotahitanga, or "unity movement," had mobilized most Maori by the 1890s in a boycott of the Native Land Court, justifiably perceived as an instrument for recognizing Maori land rights only as a prelude to alienating them. They won some concessions in 1900 in the form of committees and councils to manage the remaining Maori land, but when these proved reluctant to alienate land, the land councils (renamed boards) were soon put under the control of their Pakeha members. Piecemeal land alienation, under the individualized titles awarded by the Native Land Court, continued; indeed the Maori Land Boards were given certain compulsory authority under new legislation to take control of undeveloped land and alienate portions of it (Williams 1969:33-129).

All the while, Maori involved in the kotahitanga-or those who brought actions in the superior courts-tried in vain to cite the Treaty of Waitangi as the foundation of their rights in the New Zealand state. There grew up two histories of New Zealand, running parallel and rarely touching each other (Orange 1987a:159-225). The general settler and official version was that Maori had been given the full rights and privileges of British subjects from 1840 in a remarkable 
effort at racial "amalgamation" and equality unique in British colonization. If this had exposed them to certain commercial risks, through the transformation of their customary land tenure into individual marketable titles, that was one of the hazards of entering into the modern world. And indeed, by 1900 some Maori had prospered, become farmers, gained education, graduated from universities, held seats in parliament, intermarried with the Pakeha, been ordained in the Anglican clergy, shared in the local sporting clubs and social venues. It was New Zealand's proud boast, not entirely without foundation, that the age-old problem of intercommunal relations had been solved in a society where racial equality was real. Pakeha did not mention the treaty much in their discourses but, except for the few who got closer to Maori realities and viewpoints, they considered that they had honored it.

The majority Maori version of post- 1840 history was very different. They had genuinely sought to engage with the incoming new world, the world of money and commerce and economic development, with the British settlers who knew about these things, and with the machinery of state that had undertaken to protect their rangatiratanga and their fair share of status and wealth in the new order. Instead they had found themselves fobbed off with tokenism and condescension. Economically, they had been systematically marginalized. Most Maori lived in rural slums, amidst harsh poverty and appalling health. Lacking access to capital, they had had to sell far more land than they intended in order to buy commodities and to start their own ventures. Caught in a debt trap, they had to sell yet more land. Factionalism and pseudo-individualization of titles enabled the purchasers to take advantage of inexperience and cupidity (Ward 1974:308-315). It was no accident that both the formally educated and traditional leaders at the turn of the twentieth century made demands for $h a p u$ based rather than individual control of land and for capital for development, already available to Pakeha under the Advances to Settlers Acts. These modifications were grudgingly admitted by settler governments in respect of portions of remaining Maori land-about 4 million out of 64 million acres were left in the 1930s.

After the First World War, in which Maori soldiers fought alongside Pakeha comrades, a new effort to secure ratification of the treaty was made by the Ratana Church, founded by Wiremu Ratana after 1926, again with the traditional features of prophecy and faith healing, but looking always to gain access to modernization and genuine 
socioeconomic equality. A remarkable compact between Ratana and the leaders of the emergent New Zealand Labour Party saw Labour choosing Ratana candidates as its nominees for the four Maori seats in parliament. By 1943 they had won all four and were crucial to Labour retaining office (Henderson 1963:85-106). Even so, Labour's policy, in its long period of government from 1935 to 1949, did not substantially alter the direction of policies toward Maori. Labour's Keynesian-style economics, its housing, medical, and family support systems, its extension of state secondary education to rural areas, benefited the Maori poor more than the Pakeha poor only because Maori were previously worse off. The Maori Social and Economic Advancement Act of 1945 revived the network of tribal committees to assist in the delivery of welfare and increased support for Maori farming (Orange 1987b). Some very limited payments were made to tribal Trust Boards in recompense for land confiscations, acknowledged by a commission of inquiry in the 1920s to be unjust. Full employment and state housing schemes enabled a massive Maori urban migration to occur relatively painlessly. From the non-Maori perspective, the integration of Maori and settler into one New Zealand society seemed entirely successful.

Most New Zealanders then were taken completely by surprise when this Maori hidden history erupted into increasingly fierce protests from the late 1960s. The trigger, appropriately enough, was a set of seemingly innocuous amendments relating to Maori land in the annual "wash-up" bill of 1967. Maori land titles had become increasingly fractionated as the Maori population burgeoned and the interests of one generation were divided among many descendants in the next. It seemed only sensible to the planners, including Maori planners in the Department of Maori Affairs, to pool these "uneconomic interests" and to convert some categories of "Maori freehold land" into "general land," able to be leased, mortgaged, willed, or even sold without any of the confused constraints that now applied to Maori land. But to Maori, the bill was an act of latter-day paternalism at best and threatened the remaining land interests of many Maori, hence threatening their identity. New Zealand was in fact on the eve of a vast Maori cultural resurgence. Protest was led by educated young Maori and by the official New Zealand Maori Council, formed in 1962. They were quickly joined by widespread urban and rural protest organizations (Kawharu 1977:251-293; Walker 1991:615-624). Land occupations began on blocks acquired (like Raglan golf course) 
or about to be acquired (like Bastion Point in Auckland city) under planning legislation. A great "land march" from North Cape to the parliament in Wellington was organized by the protest groups and led by a venerable kuia, a leader of the Maori Women's Welfare League, Dame Whina Cooper (Ward 1991:97-98). Meanwhile, the period of economic boom and full employment had given way to recession and unemployment. This intensified the problems of newly urbanized Maori. The social control exercised in semitraditional fashion in rural areas was not wholly reestablished in the cities, and crime and violence among young Maori rapidly increased.

In Parliament, Maori Ratana/Labour members continued to press for statutory recognition of the treaty as an important step toward recognizing Maori rights and needs (Orange 1987a:232-249). In 1975 , "with the footsteps of the land marchers ringing in their ears" (as one Opposition speaker taunted), the Labour government accepted a bill proposed by Mr. Matiu Rata, minister for Maori Affairs, which provided that, henceforth, any Maori or group of Maori who considered they were prejudicially affected by any act of the Crown or its agents in breach of the principles of the treaty, could bring a claim to a new tribunal, the Waitangi Tribunal. This body, comprising three Maori and Pakeha members, would act as a commission of inquiry, investigate widely, and make recommendations. The Treaty of Waitangi Act was not retrospective, and many Maori groups-such as the Ngai Tahu of the South Island, who had for a century pursued their claims arising from the Crown's acquisitions of the island in the 1840s and 1850s-were disappointed. Few claims were brought to the tribunal and major demonstrations, sometimes violent, continued, notably on Waitangi Day itself, established by Labour as a national holiday but rapidly becoming a focus of protest.

In 1982, however, Mr. Edward ("Eddie") Taihakurei Durie became chief judge of the Maori Land Court and, ex officio, chairman of the Waitangi Tribunal. Durie began to use the tribunal's investigations and reports to spell out the principles of the treaty, to develop a bicultural jurisprudence, and to review history that bore on the contemporary issues at hand. The Motunui report of 1983, for example, concerning the pollution of a fishing reef by sewage from the town of Waitara (the very same area over which war had begun in 1860) emphasized Maori spiritual and cultural values in relation to seafood and to water. It advocated a more genuine place for Maori in the control of such resources, as a treaty right. Subsequent reports spelled out the 
historical relationship between Maori and settler in respect of planning and conservation and the impact of colonization on Maori resources and values, reaching back to 1840 (Oliver 1991:10-17; Renwick 1990:16-44). Largely the product of Durie's subtle mind and writing skills, which eschewed legalistic and jargonistic language, the reports evinced an essential reasonableness and powerful but gentle reminders of the engagements the Crown had solemnly and publicly entered into with the Maori.

Sensitive to its somewhat undeserved reputation for good race relations and bewildered by the escalating social problems and protests, middle-class New Zealand began to look to the Waitangi Tribunal as an avenue for reform. A huge hui, an "economic summit" in effect, convened at Ngaruawahia, the seat of the kingitanga, in 1984, called for a significant transfer of resources back to Maori ownership and control in order to relieve Maori marginality, unemployment, and sense of alienation in their own country. The concept was thus born of linking the resource transfer to the investigation and redress of historical injuries. In 1985 the Labour government of David Lange amended the Treaty of Waitangi Act to give the tribunal jurisdiction back to 1840 .

The amendment-a two-line amendment to the principal act-reflected the ignorance of the Labour ministers (in particular the attorney-general, Geoffrey Palmer) of New Zealand history and Maori understandings of it. It was apparently assumed that the grievances would be relatively few and manageable-the land confiscations of the 1860s, taking of Maori land for public purposes and not returning it when it was not required, unfulfilled promises about reserves in Wellington and the South Island, for example. The legislators did not apprehend that for Maori, the key issue was the treaty guarantee of tino rangatiratanga and its erosion by myriad acts of the Crown since 1840. Most notably they did not apprehend that, in many Maoris' view, the Native Land Acts, while initiating a process of legalized transfer of Maori land, had seriously distorted or misconstrued customary rights. Under the Treaty of Waitangi Amendment Act of 1985, virtually all Maori land transfers could be reviewed.

Thirty or forty claims were lodged in the first two years after the amendment. Claims then grew rapidly to 88 in 1987, 216 in 1991, 289 in 1992, 360 in 1993, 442 in 1994, and 720 by 1998, at which date about 190 had been investigated and reported upon, 31 settled by direct negotiation with the government, and 19 withdrawn (Waitangi 
Tribunal annual reports). Many claims overlap because of competing tribal or factional interests in the same land. The tribunal was expanded to seven members in 1985 and sixteen in 1988 (comprising senior Maori and Pakeha community leaders, as well as lawyers and academics), with several panels working simultaneously. Its research staff was also expanded, and claims were grouped and treated on a regional basis as far as possible. Even so, the researching and hearing of claims cannot possibly keep up with the applications if serious investigation is to be done.

The complexity of the process was revealed in the first major set of claims heard in the post-1985 process, those of the Ngai Tahu tribe of the South Island. The claimants used professional historians both to comb the documentary record and to assemble oral tradition. The Crown did the same, appraising the evidence of the claimants and adding much of its own. The tribunal itself also hired historians to appraise Crown and claimant evidence and to fill any gaps in the research. The exchange of argument, rebuttal, and fresh submissions went on for three years. Evidence and inference from evidence were very finely weighed. In the process, manifold different understandings were revealed that would delight any cultural relativist or "montage" historian.

It is perfectly obvious, of course, regardless of any tendentious selection or weighting of evidence to show the Crown guilty or innocent of wrongdoing in the great South Island purchases of the 1840s and 1850 s, that various versions of what happened were genuinely held by different parties. What was "true" for one was not "true" for another. One of the great values of the Waitangi Tribunal proceedings is to enable Maori claimants to voice their understandings and concerns about land alienations before a tribunal of the state, including known and reputed Maori leaders. The satisfaction of voicing their longsubmerged histories is one of the reasons for the outpouring of claims. An important outcome for non-Maori (for those who care, at least) is a much better understanding of Maoris' sense of grievance and alienation, even if Maori claims are not found to be well grounded, or not wholly so.

But the Waitangi Tribunal, and the general public behind them, have not the luxury of merely noting different "discourses" or perceptions of the past and accepting the relativist position that the various Maori perceptions are as equally valid as one another or as the various versions delineated by Crown or tribunal historians. The tri- 
bunal is obliged to try to disentangle fact from myth or misunderstanding as far as possible, even while acknowledging the multifaceted nature of "facts" and the reality of mythological and symbolic meanings. Its statutory obligation is to determine whether actions by the Crown breached principles of the Treaty-principles that were defined by the Court of Appeal in 1987 as including the duty of "active protection" of Maori rights (consistent with evident public necessity), consulting meaningfully with them on matters affecting them, and dealing with them reasonably and with the utmost good faith.

The task of disentangling and decoding the evidence was addressed again and again in the Ngai Tahu proceedings, in the seemingly small as in the great matters. Thus, among Ngai Tahu there was a belief that a British warship had conveyed the northern chief Te Rauparaha (of Ngati Toa) on his devastating raids on Ngai Tahu in 1830 in order to make them more amenable to land selling. However, there is a substantial documentary record to show that Te Rauparaha was conveyed south by a merchant captain, Stewart, in exchange for a cargo of flax, and that, far from condoning the incident, the authorities in New South Wales prosecuted Stewart in their courts. Notwithstanding the popular belief among Ngai Tahu that stems from a tendency to see the British Crown as the root of all their evils, the Crown was not to blame on this occasion (Ward 1990:151-152).

Important issues about memory and silence arose in respect of the Otakou purchase of 1844 for the settlement of "New Edinburgh," or Dunedin. The central issue was the extent of reserves promised to the vendors. In 1844 Governor FitzRoy was initiating a policy of reserving to the Crown a tenth of all the sections in subdivision sales as an endowment principally for Maori purposes. But the "tenths" had proved dissatisfying to Maori in Wellington, and in the tribunal the Crown produced evidence to show that in Otakou, Maori preferred reserves in three or four bigger blocks, in their own name-notably their own little township built with the whaling captains at Otakou heads. The claimants in 1987 argued that there were still unfulfilled promises of "tenths" in Dunedin itself, and that the Ngai Tahu had never ceased to press for these. There was, however, no sign of evidence in the documentary record of any early protest on the matter after 1844 , despite detailed records of protest on other matters when the governor or a minister visited the area. Not until 1867 did protest really surface, and then it was over a particular canoe landing site and hostel in Dunedin (Waitangi Tribunal 1989, Document Wai 27, 
T1:73-109). The tribunal found that there was no unfulfilled promise of "tenths" in New Edinburgh.

In subsequent discussion at the New Zealand Historical Association conference of 1990, some speakers alleged that the proceedings of the tribunal were Eurocentric in that they favored Pakeha written evidence over Maori oral tradition. Tribunal scholars argued that it was not a question of Maori or Pakeha, written or oral, but that the earliest evidence was preferred to evidence generated later, that evidence of the words and actions of the participants at or immediately after the events at issue were thought more significant for the purpose of assessing breaches of the treaty than the evidence of traditions or understandings that grew up subsequently (Ward 1990).

These matters also arose in respect of the Canterbury purchase of 1848. A key issue was whether the western boundary extended only to the foothills of the Southern Alps, or right across to the west coast, including the Alps in the sale. In February 1848, Ngai Tahu leaders had met with Governor Grey and made an offer that clearly referred only to the Canterbury plains and foothills. But in June 1848, the actual land purchase commissioner, Kemp, negotiated for all Ngai Tahu interests from coast to coast. Given that he had spent three days discussing the purchase with Ngai Tahu chiefs visiting his ship, given that he had drawn up and displayed on the deck a large map showing the western coast and place names on it provided by the chiefs, given also that several chiefs thereafter discussed reserves on a coast-to-coast basis, the tribunal rejected the 1987 assertion by the claimants that they had not included the mountains in the sale.

This discussion nevertheless yielded very important evidence of different cultural understandings about what "sale" meant within general boundaries. At a Commission of Inquiry of 1879 (when verbatim evidence had been taken in Maori), an elderly Ngai Tahu chief, Tiramorehu, said that he and his kinsmen had intended to keep the use of the swamps and streams and valley floors for their traditional economy, and named a range of such areas. When asked, "What land then did you sell to the government?" he replied, "The same land." In other words, he considered that a number of different interests could coexist in the same land, held by different parties. That was the way of things in Polynesian tenure, not sharply defined zones and boundaries or the English concept of "exclusive possessions." He had no difficulty including the Pakeha as graziers on the ridge tops (Ward 1994, reference to the evidence of Tiramorehu before the Smith-Nairn 
commission, 1879). Fortunately for Ngai Tahu, the Kemp deed had reserved mahinga kai-places of hunting and gathering-to the vendors, and the tribunal upheld this claim and many others in the package of claims lodged in 1987.

The question of Maori understandings of $t u k u$ and hoko-Maori words generally used to translate the English "sale"-was heavily at issue in the Muriwhenua claims in the far north of the Northland peninsula, a remote region. Several noted New Zealand anthropologists-Dr. Margaret Mutu, Professor Anne Salmond, and Dame Joan Metge-presented submissions to the effect that Maori in the 1830 s and 1840 s could not have conceived of sales as complete and permanent alienations. They argued that a "tuku whenua" was a grant of use rights, conditional on good behavior and continued exchange of prestations, and with certain uses of the ground by the Maori group also continuing (Waitangi Tribunal 1991, claim Wai 45, Documents F-12 [Mutu], F-13 [Metge], D-17 [Salmond]). The basis of the anthropologists' argument was cultural structuralism, a delineation of traditional institutions, and historical evidence (Waitangi Tribunal, Wai 45, F-17) that Maori views of transactions persisted into the period of settlement and land "sales."

Rebuttal came from two directions. Ms. Lindsay Head, a linguist, basing her arguments on the Maori texts that accumulated rapidly when Maori became literate in the 1830s, showed considerable variation in the meanings of tuku and hoko. She considered the anthropologists' arguments to be altogether too reductionist and reifying (Waitangi Tribunal 1991, Wai 45, F-21). A historian for the Crown, Mr. Fergus Sinclair, then combed exhaustively the voluminous missionary records from the wider Northland region and showed that many Maori there had been involved in commerce for two decades and had very clear notions of full and permanent transfer. It appears that some deliberately sold land, in the European sense, in the 1830s, for a variety of reasons, often moving away from the areas sold and leaving missionaries or other settlers in undisturbed possession (Waitangi Tribunal, Wai 45, 1993, I-3). The tribunal reported on the Muriwhenua claims in 1997 and found strongly in the claimants' favor. Maori worldviews clearly operated at the time of the land transactions, and very few settlers arrived to disturb it before 1865 (Waitangi Tribunal, 1997, Muriwhenua Land Report).

The debate is far from finished, but taking a broader and more national perspective, the treaty-related research suggests at least three 
main phases in Maori attitudes to land sales. Early "alienations" of huge tracts in the 1820s and 1830s in the South Island show very plainly that Maori were including the Pakeha into their own society and expecting them to behave accordingly on land that was still seen as under Maori mana. Then, in the 1830s and 1840s, especially in the north (with European shipping and settlement abundant), there appears to have been a phase of competitive selling between hapu who had overlapping interests in a relatively small area. One motivation appears to have been to sell before someone else sold the land from underneath one; selling was a kind of assertion of mana, with Maori perhaps not yet appreciating that (according to the British) they no longer had any rights in the land. Later, in the 1850s, there was a widespread revulsion against this trend, particularly in South Auckland, Hauraki, and Hawkes Bay. Throughout the North Island, tribal (not $h a p u$ ) and supratribal organizations emerged to stop the competitive selling. In remote areas such as Poverty Bay, it began to be made clear to settlers that the earlier transactions there were not considered sales of absolute title, partly because not all rightholders had been involved and partly because Maori were not thinking in these terms anyway.

The main vehicle for this analysis is empirical history, focused by the claims brought against the Crown and informed and enriched by much better understandings of Maori values and institutions. In the process, the dichotomies between oral and written and Maori and Pakeha evidence break down. For example, Maori have become aware of the very rich stock of Maori-language documentation from the 1830s and are thronging the archives to find out what their tupuna wrote, or their words as recorded by others. The vast records of the Native Land Court, recording the whakapapa and other oral testimony of Maori leaders from 1865, are being tapped extensively (Dr. Angela Ballara's book Iwi: The Dynamics of Maori Tribal Organisation from c. 1769 to c. 1945, Victoria University of Wellington Press, 1998 , is a fine product of this research). Not much high theory is involved in this, but hermeneutic and semiotic understandings are habitually invoked in the detailed explication of "what happened" or of what was culturally constructed and understood. There is constant recognition that, as in the Ngai Tahu examples cited above, different understandings were sometimes held by various parties to the same action. Misunderstanding was obviously commonplace, but the evidence of mutual understanding between Maori and Pakeha actors on 
an ongoing basis is also strong. Frequently it is plain that each understood the other all too well, and that the jockeying for control created an inexorably mounted pressure over twenty years as Maori or Pakeha sought to make the other conform, until the cataclysm launched in 1860 by Pakeha who recognized that an impasse had been reached and sought to enforce their system of land title and land purchase by use of the army.

Although there is increasing mention in anthropology departments of a distinct Maori epistemology, the tribunal's essentially nonrelativist view of history meets the current purposes of most Maori perfectly well because the research shows the Crown to have been in the wrong, again and again, in terms of Maori treaty rights and even of common-law rights. Apart from the tuku whenua debate, there is no widespread call for a general relativized view based on cultural dichotomy and "talking past each other," although that is apparent in specific matters. The tribunal's tendency to distinguish, where appropriate, between the understandings of the actual Maori parties to a land transfer and the modified understandings ("myths") that grew subsequently is not always pleasing to Maori claimants.

Another pressure toward a culturally sensitive but positivist view of the evidence of the past is the rapidly increasing competition between Maori groups for the same land or for the Crown's compensation payments. Historians and anthropologists alike have shown that Maori whakapapa (genealogy and associated stories) were quoted selectively by the tellers to support claims against rivals (Ballara 1991; Binney 1987; Salmond 1991). This was consistent with the constant flux in the human boundaries of $h a p u$ and $h a p u$ clusters. Traditionally, Maori society had happily used this process to maximize group strengths and control over resources. But of course it did not result in tidy boundaries between groups and their lands.

The contact period, the very fact of landselling, and the later process of proving claims in the Native Land Court after 1865 (with one group "winning" and the others "losing" in the Pakeha-dominated judicial process) produced a quasi-reconstruction of Maori social order. About forty major "tribes" were identified and maps drawn with neat "tribal" boundaries demarcating them. Scores of other iwi (tribal) or hapu names disappeared from the public record. The resulting orthodoxy, shaped by the Land Court and early Pakeha anthropology, came to be accepted by many Maori themselves.

The treaty processes have blown all this to the four winds. To the 
puzzlement and sometimes the dismay of modern Maori leaders, the submerged traditional dynamics and complexity of Maori social order has reasserted itself with astonishing vigor. The Ngai Tahu "tribe," for example, tenuously held together for the purposes of the claim by Sir Tipene O'Regan, has since produced fiercely independent claims by Waitaha hapu in the far south and Tuhuru hapu on the West Coast, with the latter represented by the able member of parliament, Sandra Lee, a constant irritant to Sir Tipene. In 1990, the Labour Government enacted a Runanga Iwi Act to empower local iwi councils and to replace the centralized Department of Maori Affairs with an "Iwi Transition Authority" (ITA). The intention was to decentralize expenditure and promote real self-determination at iwi level, but with positions and budgets on offer, Runanga Iwi proliferated across the country, absorbing development funds in fees and expenses. O'Regan jibed at the "add water, instant iwi" phenomenon and the integrationist Maori leader, Winston Peters, briefly minister for Maori Affairs in the National Government of 1992, abolished the Runanga Iwi and the ITA.

But the tendency toward reassertion of local hapu identity is real and fundamental nevertheless, and it constantly bedevils attempts at treaty "settlements." Negotiations over valuable railway lands in central Auckland and central Wellington in 1992-1993 produced claims not only from Maori groups now resident in the area, but from groups defeated and expelled in intertribal war just before white settlement. They had left their place names and their dead on the land too, they argued; they too were therefore tangata whenua-people of the land. The conquering groups expostulated; the defeated parties might have certain sacred sites (wahi tapu) where their dead lay, they acknowledged, but mana whenua, the authority over the land, generally lay with the invaders. Yet, say the defeated, the invaders intermarried with us; we too can "whakapapa in" to those lands (Ward 1993:196-200).

Most recently the urban immigrant groups, now in their second and third generation of residence in the cities, have also begun to claim rights as tangata whenua of those lands. The terms "tangata whenua" and "mana whenua" have thus become problematic. Clearly there were various claims of right to land, but how were the priorities between them decided? Was it essentially a matter of dominant power? Or (as the Moriori of the Chatham Islands argue against their Maori conquerors of 1835) did conquest only give mana tangata, not mana whenua, which still lay with the first occupants? And when did rights grow so "cold," by nonresidence, as to cease altogether? 
These questions are so serious and so contentious for modern Maori (let alone for Pakeha administrators) that Chief Judge Durie has recently secured the cooperation of the New Zealand Law Commission to launch a research project, designed to run over four years, into Maori customary law. The project has since been taken over by the Law faculty of the University of Waikato. The research will be cross-disciplinary and biracial, involving Maori elders and Maori and Pakeha academics and lawyers. It was intended to focus on determining a Maori "jurisprudence"-that is, the principles and values underlying customary practices, as well as the customary practices themselves. The long series of meetings and discussion papers will involve Maori people throughout the community in what is hoped to be both an intellectual decolonization and to revive values and procedures that will enable Maori to resolve differences and work for mutual advancement in modern New Zealand. Similar research projects have been launched by the Maori Studies faculty of Massey University.

Meanwhile, efforts at transfer of resources to Maori have begun, notably in the area of sea fisheries. Maori claims to unextinguished rights in the sea and foreshore were greatly assisted by a 1986 decision of the High Court in the case of Te Weehi v. the Regional Fishing Officer. When charged with taking undersized shellfish, Te Weehi claimed to be exercising a customary fishing right. The trial judge referred to recent Canadian judgments such as Calder's case, Guerin's case, and Sparrow's case and found similarly: That unless expressly extinguished by legislation, customary rights survive the transfer of sovereignty. The superior courts also supported claims by the New Zealand Maori Council in support of Waitangi Tribunal findings in the Muriwhenua Sea Fisheries report, and ordered the Crown to negotiate with Maori representatives (McHugh 1991:130-132).

The negotiations came dramatically to a climax in 1992 when the giant Sealords fish processing corporation put much of its shareholding on the market. The government offered the Maori Fishing Corporation NZ\$150 million to purchase the shareholding, plus 20 percent of fishing quotas not yet allocated, as full settlement of Maori commercial fishing claims. Maori were deeply torn between accepting an excellent offer, including immediate ownership of much of the fishing industry, and signing away indefinitely their treaty claims to commercial fisheries. Given that the Crown would have contested further claims in the courts, it was sensible to accept. But the subsequent allocation of the quotas and interests between Maori has proved very divi- 
sive, pitting the iwi (tribes) claiming customary control of long coastlines against the inland $i w i$, some very numerous, who seek a distribution mainly on a population basis. Well-organized urban Maori groups in Auckland, such as the Waipareira Trust, have also claimed recognition as $i w i$, entitled to share in the distribution of fishing quotas. Interim arrangements have been made, but the issues are repeatedly before the courts.

The intensity of feeling over the divisions of the fisheries has caused Maori leadership to be increasingly concerned about the basis of eventual distribution of remedy for historical claims about land. The New Zealand Maori Council was again successful in the High Court in an action regarding the sale of Crown assets in the government's privatization policy, launched in 1986. Crown lands and forests, coal, hydroelectricity, and geothermal power are assumed by Maori to be important sources of redress for historical injury. On behalf of claimants, the Waitangi Tribunal secured the addition of a clause in the State Owned Enterprises Act of 1986 requiring the Crown to act consistently with the principles of the treaty. The following year the Maori Council secured a High Court judgment to the effect that the Crown had a duty "analogous to fiduciary duties" to affirm those principles, the court noting that the duty of the Crown "is not merely passive but extends to active protection" of Maori people's interests in lands and waters. The Court again required the Crown to satisfy it that the Treaty obligation in the SOE Act would be complied with. The outcome was that memorials were placed in the titles of land sold by state-owned enterprises whereby the Crown would be obliged to buy back the land if it was determined necessary by the Waitangi Tribunal to remedy a grievance (Renwick 1990:57-59).

A similar question arose in regard to Crown forests, between 10 and 20 percent of which are estimated to be on land still technically Maori land or land acquired in breach of the treaty. The government established a Crown Forestry Rental Trust (CFRT) to receive rentals and cutting-rights payments, pending determination by the tribunal, of claims over forested land. The trust meanwhile was authorized to fund research by and on behalf of the claimants in respect of these lands (Renwick 1990:73-76). The CFRT is now by far the best-funded organization for research in New Zealand history. Not surprisingly, some of the most able young historians in the country are now working for tribal groups on CFRT funding. This, to some extent, has sapped the research skills of the tribunal itself, which is tied to public 
service salary scales, with a resultant threat to the institutional knowledge of the tribunal.

Nevertheless, CFRT and tribunal researchers collaborate in the shaping of projects. Many of these fall within a program called Rangahaua Whanui ("Research Widely") launched by Chief Judge Durie in 1993. The purpose of this project was to supplement research done in respect of claims, which are inevitably somewhat capricious and incomplete in their coverage. Various themes, such as the operation of the Native Land Acts in the nineteenth century or of Maori Land Boards in the twentieth, have national application; projects on these themes relate to most or all local claims. By these means the tribunal is seeking to meet the research needs of treaty-related claims, increasingly numerous and complex as they are. Meanwhile, the Pakeha electorate and successive governments have been increasingly impatient of the proliferation of Maori claims and the high value of settlements sought by Ngai Tahu (on the basis of the exhausting tribunal report on their claim) and by the Tainui tribes, the core of the kingitanga whose claim for compensation for land confiscation the government has, in principle, acknowledged. Very high expectations have been generated among Maori by the 1985 amendment and the legislation affecting SOE assets and Crown forests. Estimates of the total value of Maori claims range as high as $\$ 93$ million, far beyond the capacity of the economy to bear. By 1994, with no agreement on a benchmark settlement and both government and Maori impatience rising, the government—guided by Mr. Doug Graham, minister for Justice and minister in charge of Treaty of Waitangi negotiations-sought to impose what it regards as realistic bounds on the whole process.

On December 8, 1994, amidst considerable fanfare, the government released a set of "Crown Proposals for Settlement of Treaty of Waitangi Claims." The essence of the proposal was a "Fiscal Envelope" or "Settlement Envelope" of $\$ 1$ billion, less the direct cost of the fisheries settlement, estimated to be $\$ 170$ million, and less research costs funded by the Crown since September 1992. This sum was fixed and nonnegotiable. All other settlements of historical grievances were to be met from this "fiscal envelope" over about a ten-year period. Each claim was to be individually negotiated and settled; there would be no "global" or pan-Maori settlement. The government would require to be satisfied that Maori negotiating parties were properly recognized representatives of their group; the Waitangi Tribunal or the Maori Land Court could hear objections on that point. A date by which historical claims should be lodged would also need to be agreed upon. 
The proposal immediately met with concerted opposition from Maori. The government had hoped to oblige Maori to come to realistic negotiating positions, having regard both to the economy as a whole and to those groups coming later in the queue (rather than having Ngai Tahu and Tainui, for example, carry away the bulk of the recompense, leaving little for those who come after). From Maori points of view, however, the "fiscal envelope" invited an unseemly scramble for hopelessly limited payments. More seriously, many senior and moderate Maori leaders were affronted that the whole proposal had been determined without widespread formal consultation with Maori: They saw it as Pakeha paternalism again, diminishing Maori rangatiratanga.

Indeed, the proposal had about it the air of an attempt to stuff the genie back in the bottle, after another paternalistic and ill-considered act of government in 1985 had let it out. It is indeed understandable that government in the mid-1990s should try to bring within bounds the so-called "grievance industry" launched in 1985, but it has gone about it in a somewhat inept fashion. Just as Geoffrey Palmer and David Lange in 1984-1985 essentially bypassed much of the Maori leadership, so did Messrs. Graham and Bolger in 1994. They fear that the "grievance industry" is divisive of Maori against Pakeha, threatening to economic stability and indeed to civil order, since extravagant claims cannot be met and some Maori radicals have made threats to property if they do not get their way. But most Maori do not want instability either and are concerned about the increasingly fierce divisions between Maori that the claims have fostered. The government could well take them more into their confidence in addressing these matters. For Maori too have vested interests in the New Zealand economy. Either they are themselves entrepreneurs and farmers, or they know well that the horrendous unemployment among Maori needs to be reduced by economic development. More fundamentally, they are angry about being treated as junior players, not equal treaty partners, as the rhetoric of governments and judges since 1985 would have them believe.

Ultimately self-defeating too, probably, is the government's determination to negotiate each and every claim, with a "global" Maori settlement ruled out. For many Maori are not tribal; at the last census some 20 percent could not name their tribe. Yet Maori as a whole were injured by the landgrab. A more flexible strategy is certainly called for, with particular injuries addressed but also the systematic and structural causes of marginalization, namely the advent of a 
money economy - an economy based on capital investment among a people who could raise no capital except by selling land and who were then prevented by the divisive land laws and compulsory acquisitions from readily engaging in development themselves.

Some Maori leaders are urging that too much focus on the past is intensifying divisions and is wasteful of precious energies and resources, leading to exaggerated demands. They would settle for an adequate transfer of capital and resources to provide an economic base for each region, including interests in urban developments-a demand common to the whole Pacific region in fact. Generally, however, resource transfer to Maori remains linked to treaty claims.

Moreover, there have been some important settlements of claims. Within a week of announcing its proposals, which included the "fiscal envelope," the government announced that it had reached agreement with the Tainui tribes of the central North Island with regard to claims arising from the vast confiscations of land in the Wiakato Valley in the 1860s. The settlement was for $\$ 170$ million, partly in land (including that upon which the University of Waikato has been built) and partly in cash. Although not all hapu were content with a settlement far below the current value of the land taken, Sir Robert Mahuta and the central leadership of the kingitanga (essentially a Tainui organization) believed that time was important: With capital of that order they could set about achieving their social, economic, and educational goals and buy back more land in the bargain. So far, their management strategies suggest that their optimism is entirely justified.

In 1997, Ngai Tahu also agreed with the Crown a settlement package of $\$ 170$ million in land and money. Ngai Tahu also won important rights of comanagement in the conservation estate, which is so important to both Maori and non-Maori in New Zealand's beautiful South Island.

In the light of the Tainui settlement and of research that has shown the level of claims settlements still to be faced, the coalition government that took office in late 1996 declared that the fiscal envelope of 1994 was no longer official policy and that existing levels of settlement would be regarded as a benchmark for future settlements. The Tainui (Waikato confiscation) claim is widely accepted to be one of the three or four biggest historical treaty claims. It may be assumed that others will be ranked against it.

Unfortunately, although the Waitangi Tribunal had issued more 
reports favorable to Maori claimants (notably regarding Muriwhenua and the Taranaki district, where some 1.2 million acres were confiscated in the 1860s), no other major settlements with the Crown have yet been agreed to. This is largely because of the complex divisions within Maori society, where each hapu is jealous of its mana and reluctant to surrender the power of negotiation (and the assets that might follow) to an overarching central body. Yet if settlement funds and assets were divided among the many hapu in a district, the development opportunity offered by a substantial pool of capital and assets would be dissipated. The Waitangi Tribunal has power to mediate between contending $h a p u$, but there is a growing need for it to be given a statutory power of arbitration as well, so that the rights of hapu are not overlooked by a central multitribal authority-but that an intransigent $h a p u$ cannot frustrate the opportunity for benefits to flow to the wider Maori community of the area.

The treaty claims process in New Zealand has evolved remarkably over the last ten years to the point that relevant systems of knowledge, both Maori and non-Maori, have been brought to bear very effectively to evaluate Maori claims regarding breaches of treaty principles. There have been enormous benefits from this in terms of understanding of Maori culture and Maori history-understandings that are seeping into the public consciousness and the formal education systems. Maori, too, have recovered a sense of their own identity, at $h a p u$ as well as tribal and national levels, and a much greater understanding of just what happened to them during colonization. As regards the retransfer of wealth by way of reparation for breaches of the Treaty of Waitangi, it is almost as if Maori society had become too dynamic. Adjusting the traditional social order to the exigencies of the modern world has been a demanding and ongoing task since the eighteenth century. It poses difficult new challenges to Maori today, and there is some danger of polarization between the pragmatic Maori leaders who desire to reach swift settlements with the Crown and the traditionalists who assert a kind of tribal ( $h a p u$ ) fundamentalism, competing with their kin for large shares of the settlement assets. The controllers of knowledge systems in New Zealand have a huge responsibility to understand all sides of these complex processes and help their clients-in particular Maori students in schools and universities - to appreciate their history, their tradition, and the change in their society and thereby secure greater control over the choices that confront them. 